Modern Asian Studies 52, 2 (2018) pp. 492-531. (C) Cambridge University Press 2017 doi:10.1017/Soo26749X16000391 First published online 10 November 2017

\title{
Caste and Cross-region Marriages in Haryana, India: Experience of Dalit cross-region brides in Jat households*
}

\author{
REENA KUKREJA \\ Global Development Studies, Queen's University, Kingston, Canada \\ Email:kukreja.reena@queensu.ca
}

\begin{abstract}
This article, based on original research in 75 villages in the North Indian state of Haryana, examines long-distance marriages of its dominant-peasant caste men with low-caste (Dalit) women from other parts of India. The male marriage squeeze caused by the female deficit in Haryana has led to this breach in the rules of caste endogamy in matrimony. These marriages and the gender status of such Dalit brides are situated within the context of polarized caste relations, caste contestations, and caste violence against local Dalits in Haryana. Long-distance alliances, through fabricated, high-caste identities of the brides, tactically circumvent prohibitions on local inter-caste marriages and provide legitimacy to continued, local, unequal hierarchies of caste relations. Intersecting oppressions of caste, gender, and patriarchy exacerbate gender subordination within both the home and community for Dalit cross-region brides. Caste-exclusionary behaviours and discriminations are strategically employed to assert caste supremacy and subdue women's resistance. The caste stigmatization of these brides carries over to their children who face inter-generational discrimination in daily interactions and marriage prospects because of their 'diluted' Jat identity and low-caste status. The article provides examples of Dalit brides' agency through resistance strategies.
\end{abstract}

\section{Introduction}

Since the mid-1990s, the male marriage squeeze caused by the female deficit in North India has led locally rejected bachelors from states

* I gratefully acknowledge Paritosh Kumar, Mike Mason, Abigail Bakan, and the two anonymous reviewers for their insightful comments on earlier drafts of this article. I am indebted to Urmila Kukreja for making me pursue my focus on Dalit brides in cross-region marriages. I am thankful to the Social Sciences and Humanities Research Council, Canada Doctoral Award $75^{2} 2014$ 2052, and the Royal Norwegian Embassy, New Delhi, India, for funding this research. 
like Haryana and Rajasthan to travel to distant and economically marginalized parts of India like West Bengal, Assam, and Odissa to seek brides. These long-distance ${ }^{1}$ or cross-region marriages ${ }^{2}$ are largely at tributed to the bride shortage caused by a pervasive mentality of girl dis-preference intersecting with the family planning policies of the Government of India and new reproductive technologies. ${ }^{3}$ These marriages are transgressive of customary norms of marriage among Hindus, as the brides belong to a different caste, ${ }^{4}$ ethnicity, region, and, sometimes, even religion than their husbands.

Among Hindus, caste plays a determining role in marriage as it is the linchpin through which unequal caste hierarchies are reproduced. ${ }^{5}$ Caste endogamous marriages are customarily conducted within the same jati or sub-caste group while following the rules of both clan groups (Got or Gotra) and village or territorial exogamy. Inter-caste marriages are considered taboo, and individual autonomy in mate selection is usually overridden in favour of pragmatic matrimonial choices to ensure that caste hierarchies that otherwise might get eroded are maintained. Though hypergamous alliances often involve different regions, there is usually a geographical boundary marking the imaginary cut-off for such unions; it can comprise 'a few

${ }^{1}$ Shruti Chaudhry and Tanisha D. Mohan, 'Of Marriage and Migration: Bengali and Bihari Brides in a U.P. Village', Indian Journal of Gender Studies, Vol. 18, No. 3, 2011, pp. 311-340.

${ }^{2}$ Ravinder Kaur, 'Across Region Marriages: Poverty, Female Migration and the Sex Ratio', Economic and Political Weekly, Vol. 39, No. 25, 2004, pp. 2595-26o3.

${ }^{3}$ P. Jha, M.A. Kesler, R. Kumar, F. Ram, U. Ram, L. Aleksandrowicz, D.G. Bassani, S. Chandra, and J.K. Banthia, 'Trends in Selective Abortions of Girls in India: Analysis of Nationally Representative Birth Histories from 1990 to 2005 and Census Data from 1991 to 2011 ', The Lancet, Vol. 377, No. 9781, 2011 , pp. $1921-1928$.

${ }^{4}$ The traditional hierarchical kinship-economic system called the caste or Varna system is characterized by four castes or varnas arranged in a pyramid-like structure with Brahmans at the top, followed by Kshatriyas, Vaishyas, and Shudras at the bottom. Apart from these four caste groups, a significant proportion of people involved in 'ritually polluting' occupations such as handling waste or dead animals are placed outside the four-fold caste hierarchy as 'Untouchables'. Each varna is further divided into a multitude of jatis or sub-castes. Each jati is an endogamous group with a traditional occupation and ranking within a caste; intermarriage and inter-dining are usually limited to sub-groups of these. In India, 'caste' is used interchangeably with varna or jati; however, in reality, it is jati that determines everyday rules and regulations of behaviour and interaction between various sub-castes.

${ }^{5}$ Uma Chakravarti, 'Conceptualising Brahmanical Patriarchy in Early India: Gender, Caste, Class and State', Caste, Class, Gender, M. Mohanty (ed.), New Delhi: Sage Publications, 2004. pp. 271-295. 
administrative units to a whole linguistic region'. ${ }^{6}$ The geographical limit prevents ties with families whose caste credentials and status cannot be verified due to distance. In addition, spatial limits are created naturally as the desired clan groups (Gotras or Gots) for marriage alliances are normally concentrated in a particular region and not found elsewhere. Not surprisingly then, in contemporary India, religion and caste play a determining role in marriages: a 2014 survey $^{7}$ revealed that inter-caste marriages in both rural and urban India make up a mere 5.4 per cent of marriages, a figure unchanged from a previous survey done in 2004-05.

In the North Indian state of Haryana, in particular, the majority of these caste-transgressive, long-distance marriages are sought by dominant-peasant ${ }^{8}$ sub-castes of Jats, Yadavs, and Ahirs. Ritually, these three castes are located in the bottom-most Shudra varna ${ }^{9}$ that is, just above the Dalits, ${ }^{10}$ in the Brahmanical caste hierarchy. It is only ownership of the majority of the land and numerical strength that make them an economic and political force. Contradictorily, these very castes, in the recent past, have unequivocally opposed intercaste marriages of their kin with lower castes locally, with severe

\footnotetext{
${ }^{6}$ Iravati Karve, 'The Kinship Map of India', Family, Kinship and Marriage in India, P. Uberoi (ed.), New Delhi: Oxford University Press, 1994, pp. 54, 50-73.

${ }^{7}$ S. Rukmini, 'Just $5 \%$ of Indian Marriages are Inter-Caste: Survey', The Hindu, 13 November 2014, http:/www.thehindu.com/data/just-5-per-cent-ofindian-marriages-are-intercaste/article6591502.ece, [accessed 16 July 2017 ].

${ }^{8}$ The term 'dominant' caste was coined by M.N. Srinivas to refer to any caste that was numerically, economically, and politically strong in a village. See M.N. Srinivas, The Dominant Caste and Other Essays, Delhi: Oxford University Press, 1987, for more. Later theorists insisted that the dominance of a caste arose primarily from its economic power rather than its numerical strength: see Louis Dumont, Homo Hierarchichus: An Essay on the Caste System, Chicago: University of Chicago Press, 1970. Today, the term refers to a caste group that owns the majority of the land.

${ }^{9}$ The Shudra varna, though not Untouchable, comprises the peasant proprietary and artisan classes with tremendous socio-economic variations among its constituent sub-castes.

10 'Dalit' is loosely translated as 'crushed' or 'broken' in Hindi. It is a politically aware term, one that was coined in the 197os. The historically oppressed and marginalized groups considered 'Untouchables' within Brahmanical Hinduism choose to be referred as Dalits. These include a large percentage of India's population also known in official parlance as SG or ST: SG is an acronym for Scheduled Castes, a moniker for a list of caste groups contained in a schedule of the Indian Constitution who are eligible for affirmative policies of the Indian state; ST is short form for Scheduled Tribes, a term covering the indigenous population of India. Unless these terms are embedded in an interview, I will use the term Dalits when referring to these historically marginalized and oppressed castes in India. According to the Census of India 2011 , they comprise 17 per cent of the country's population.
} 
retribution, ranging from caste ostracism of errant couples to violence against a village's entire lower caste. ${ }^{11}$ Increased caste contestations between dominant-peasant castes with Dalits and violence by the former against couples in inter-caste relationships ${ }^{12}$ in Haryana have polarized rural society there and created a volatile scenario ready to explode at any perceived caste transgression.

This article situates long-distance marriages of dominant-peasant caste men of Haryana with Dalit or low-caste women from other parts of India within this caste-vitiated context. Drawing on my extensive research in 75 villages in Haryana, I contend that these marriages, in which the men violate norms of seeking mates from within their customary caste marriage pool, are undertaken tactically to circumvent caste rules and caste sanctions on local inter-caste marriages. The long-distance nature of these marriages inhibits inquiries about the brides' caste, allows fabrications about their caste to occur with ease, and thwarts challenges posed to the caste system through local inter-caste matrimonies. These alliances, instead of challenging or diluting repressive caste ideologies, heighten castebased identity politics and lead to further entrenchment of repressive patriarchal ideology through both increased and new forms of gender subordination of these brides. Lastly, I show that a range of castediscriminations are exhibited by conjugal families and communities in Haryana towards these brides because of their low-caste status and towards their children primarily on the basis of their presumed diluted caste status.

\section{Existing literature}

Scanty research has been done on the question of cross-region marriages in North India. On the one hand, a body of work by anti-trafficking NGOs has singularly chosen to highlight trafficking

${ }^{11}$ Deepender Deswall, 'Inter-caste Marriages Taking Toll in Jatland', The Times of India, 20 April 2013, http://timesofindia.indiatimes.com/india/ Inter-caste-marriages-taking-toll-in-Jatland/articleshow/19642268.cms, [accessed 24June 2017].

${ }^{12}$ News of caste-based violence against Dalits is reported almost daily. Vishal Joshi, 'Dalit Locality Attacked, Water Supply Cut After Inter-caste Marriage in Haryana', Hindustan Times, 15 April 2013, http://www.hindustantimes.com/ india/dalit-locality-attacked-water-supply-cut-after-inter-caste-marriage-in-haryana/ story-MFjl6c9WiHan6JoqU8fW2O.html, [accessed 18 July 2017 ]. 
and sexual slavery concerns about women in these cross-region marriages. ${ }^{13}$ Cross-region marriages are presented as involuntary, forced or coerced, with the brides as commodities sold and re-sold from one exploitative male to another This problematic discourse leaves no room to consider variations in experience on the basis of ethnicity, region, class or caste in its fervour to rescue 'bride-victims' caught in hyper-exploitative 'slave-like' conditions.

On the other hand, a small body of published work, ${ }^{14}$ while effectively countering the 'all brides as trafficked' paradigm, has largely focused on describing the 'adjustments' such as cultural, environmental, dress, food, language, and social practices that these brides have to make in alien surroundings. The nexus of caste, patriarchy, and gender in shaping the experiences of these brides in their new homes is overlooked as claims are made that these marriages 'unit[e] rural, illiterate Indians across boundaries of region, language, religion and even caste' 15 without disturbing the 'structural basis of caste and its hierarchies in the village'. ${ }^{16}$ The low-caste status of the brides is understood as a minor irritant that can easily be reconciled as they adjust to new caste practices. ${ }^{17}$

The failure of these scholars lies in conflating caste violence with the gender oppression that all incoming brides have to deal with in any marriage; in the process, the unequal and oppressive power relations embedded within caste-marked identities intersecting with patriarchal structures are not excavated. The persistence in regarding these brides as 'somehow unmarked or disembodied from their caste or religious identity'18 results in overlooking the narratives and experiences of Dalit brides in dominant-peasant caste households. Perhaps unintentionally, such scholarship ends up offering modern justification for caste oppression.

${ }^{13}$ Empower People, Molki: Bride for Sale, Delhi: mimeo, 2013; K.K. Pandey and R. Kant, Female Foeticide, Coerced Marriage and Bonded Labour in Haryana and Punjab, Faridabad: Shakti Vahini, mimeo, 2003.

${ }^{14}$ Avinash Ahlawat, 'Missing Brides in Rural Haryana: A Study of Adverse Sex Ratio, Poverty and Addiction', Social Change, Vol. 39, No. 1, March 2009, pp. 46-63; Chaudhry and Mohan, 'Of Marriage and Migration'; Kaur, 'Across-region Marriages'; Paro Mishra, 'Sex Ratios, Cross-Region Marriages and the Challenge to Caste Endogamy in Haryana', Economic and Political Weekly, Vol. 48, No. 35, 2013, pp. 70-78.

${ }^{15}$ Kaur, 'Across-region Marriages', p. 2601.

${ }^{16}$ Chaudhry and Mohan, 'Of Marriage and Migration', p. 337.

${ }^{17}$ Mishra, 'Sex Ratios'.

${ }^{18}$ Anupama Rao, 'Introduction', Gender and Caste: Contemporary Issues in Indian Feminism, Anupama Rao (ed.), New Delhi: Kali for Women, 2003, pp. 3, 1-47. 
My work seeks to rectify such theoretical blind spots in Indian feminist scholarship by positioning the analysis of cross-region marriages and the treatment of Dalit brides within the context of caste ideology and caste-based oppression. The intention here is not to 'produce an upper caste politics of guilt, apology and fetishization of dalit abjection'; 19 instead, my work provides a platform for the articulation of the silenced voices of Dalit cross-region brides. The first section situates these marriages within the context of contemporary caste violence against Dalits and opposition to local inter-caste alliances in Haryana by dominant-peasant caste Hindus. The focus here is to uncover the deeper motives that propel bachelors from these castes to seek 'taboo' inter-caste marriages only from distant parts of India. The second section investigates whether these alliances, the majority of which are caste-transgressive, pose a threat to the local caste structure and whether they fare the same as local inter-caste marriages in terms of 'socially sanctioned' violence or caste ostracism. The last section examines the intersection of caste, gender, and patriarchy on the lives of cross-region brides within their conjugal homes, kin networks, and community to discover if castedifference alters gender relations and/or creates new forms of gender subordination. The status of children born of such unions is examined to ascertain whether or not they suffer caste stigmatization.

\section{Theoretical framework}

I employ the framework of Dalit feminism to situate my analysis about these marriages and cross-region brides within the intersection of caste, gender, and patriarchy. Dalit feminist thought emerged in the mid-199os with the founding of the National Dalit Women's Federation, the All India Dalit Women's Forum, and also from the appearance of Dalit feminist scholars' writing on caste and gender. Dalit feminism forced a radical shift in feminist discourse in India by contending that the concerns of India's historically oppressed Dalit women, totalling over 16 per cent of India's female population, had been either ignored or silenced by upper class/caste women dominating the feminist movement in India. Dalit feminism asserted

\footnotetext{
${ }^{19}$ Anupama Rao, 'Understanding Sirasgaon: Notes Towards Conceptualising the Role of Law, Caste and Gender in a Case of "Atrocity", Gender and Caste, Rao (ed.), pp. $277,27^{6}-308$.
} 
that hegemonic Indian feminism be labelled 'Brahmani' or 'uppercaste' feminism ${ }^{20}$ for giving primacy to patriarchy while questioning women's subordination, for homogenizing Indian women and their experiences without taking into account their location in the caste hierarchy and attendant (dis)privilege, and for failing to interrogate interconnections of caste, class, ethnicity, and gender oppression. ${ }^{21}$ Dalit feminists contended that the concept of 'multiple patriarchies' ${ }^{\text {'2 }}$ operating within caste groups and between different castes should be employed in the analysis of Dalit women's everyday lived reality. Employing this framework will allow me to excavate the 'hierarchical, multiple, changing structural power relations of caste, class and ethnicity' ${ }^{23}$ in shaping the trajectory of individual and collective experiences of low-caste, cross-region brides. It will enable me to unpack the ideology of 'systemic casteness' and reticence in Indian scholarship to examine caste as a variable factor in altering the status, subordination, and oppression of cross-region brides.

\section{Research method}

This article draws from my original research on cross-region marriages conducted over four years from 2011 to 2014 in the Rohtak District of Haryana. It is a part of my larger study that focuses on two receiving or conjugal regions of Haryana and Rajasthan in North India and two sending or source regions of West Bengal and Odisha in East India. Although a number of scholarly works have been written about Rohtak District, ${ }^{24}$ these have suffered from an absence of information

\footnotetext{
${ }^{20}$ Sharmila Rege, Writing Caste/Writing Gender: Narrating Dalit Women's Testimonios, New Delhi: Zubaan, 20o6, p. 3.

${ }^{21}$ Gopal Guru, 'Dalit Women Talk Differently', Economic and Political Weekly, Vol. 3o, No. 41/42, 1995, pp. 2548-2550; Sharmila Rege, 'Dalit Women Talk Differently: A Critique of "Difference" and Towards a Dalit Feminist Standpoint Position', Feminism in India, M. Chaudhari (ed.), New Delhi: Kali for Women, 2005, pp. $211-225$.

${ }^{22}$ Mary John, 'Feminism in India and the West: Recasting a Relationship', Feminism in India, Chaudhari (ed.), pp. 52-68; Rao (ed.), Gender and Caste.

${ }^{23}$ Sharmila Rege, 'Dalit Women Talk Differently: A Critique of Difference and Towards a Dalit Feminist Standpoint Position', Economic and Political Weekly, Vol. 33, No. 44, 1998, pp. 45, WS 39-46.

${ }^{24}$ Ahlawat, 'Missing Brides'; Ravinder Kaur, 'Missing Women and Brides from Faraway: Social Consequences of the Skewed Sex Ratio in India', AAS (Austrian Academy of Sciences) Working Papers in Social Anthropology, Andre Gingrich and Helmut Lukas (eds), 2008, pp. 1-13, http://hw.oeaw.ac.at/oxc1aa5ood_oxoo1a819c, [accessed 16 July 2017 ]; Mishra, 'Sex Ratios'.
} 
about methodological frameworks or research methods informing their analysis; from a small sample size of brides ${ }^{25}$ and of villages $;^{26}$ from a lack of quantitative data about these marriages or the socioeconomic status of the grooms; and from a strong reliance on secondary sources to arrive at conclusions about the status of brides in marriages and conjugal communities. ${ }^{27}$

To carry out a triangulation of quantitative and qualitative research methods, I collaborated with Sahyog and Gramin Mahila Avm Yuva Vikas Sansthan, two grassroots NGOs that were working on issues of gender justice and caste oppression in this district. I conducted a comprehensive survey of $5^{87}$ cross-region brides in Rohtak District in all 75 villages from three community development blocks: Lakhan Majara, Sampla, and Rohtak. These cross-region brides were considered non-locals, that is, non-Haryanvi because of their different ethnicity, language, culture or region or they self-identified as non-Haryanvi by birth. The first survey was conducted in 2011, with a follow-up in 2014 to assess changing marriage trends. In addition, one-on-one semi-structured and focus group interviews, notetaking, and participant observation over a period of three years during March-April 2011 , September-December 2011 , July 201 2, and JulySeptember 2014 were undertaken.

Apart from the willingness of the brides to be interviewed, five separate qualifiers determined the choice of villages: 1) predominance of brides from one geographic region or ethnicity; 2) majority of marriages arranged by one or two marriage agents; 3) villages with the largest and smallest number of brides; 4 ) villages with the most varied duration of cross-region marriages; and 5) remoteness or proximity of villages to a town or highway. In Rohtak District, I carried out detailed research in 17 villages. Here, I interviewed 42 cross-region brides from diverse caste backgrounds in one-on-one semi-structured and focus group interviews. Of the 42 brides interviewed, 29 selfidentified as Scheduled Caste or Dalit and seven as Other Backward Castes or OBCs. ${ }^{28} \mathrm{I}$ also conducted $5^{1}$ one-on-one and 11 focus group interviews with husbands, parents-in-law, and other conjugal family

\footnotetext{
${ }^{25}$ Mishra interviewed a mere seven brides. See Mishra, 'Sex Ratios'.

${ }^{26}$ Kaur did research in two villages, while Mishra conducted research in five villages. See Kaur, 'Across-region Marriages', and Mishra 'Sex Ratios' for more.

${ }^{27}$ Kaur, 'Across-region Marriages'; Ahlawat, 'Missing Brides'.

${ }^{28}$ Other Backward Classes or OBCs is a term used for socially and educationally disadvantaged castes. It includes a number of castes ranked above 'Untouchables' but below upper castes, with a large proportion from the fourth varna or caste of Shudras.
} 
members, neighbours, villagers, and Khap Panchayat ${ }^{29}$ or caste council members.

\section{Caste violence and marriage in contemporary Haryana}

In Haryana, the three dominant-peasant sub-castes-Jats, Yadavs, and Ahirs-together constitute over 40 per cent of the population and have dominance in both land ownership and jobs in its state's bureaucracy, police, and judiciary system. Of the three sub-castes, Jats are the most powerful as they make up one-quarter of the state's population and command ownership of over 86 per cent of Haryana's fertile agricultural land. This dominance over landholding coupled with a consolidated vote bank allows them to exercise considerable clout in Haryana's politics and society. ${ }^{30}$

Rohtak District, dominated by the Jats, in particular, has witnessed tremendous shifts in the agrarian economy after India embraced neoliberal reforms in 1991. Increased urbanization, industrialization, and real estate speculation there has benefited the land-owning elites, primarily the Jats. Intensified caste contestations between the dominant-peasant landowning Jats and the Dalits, who make up the majority of the landless agricultural wage labourers, have exacerbated caste tensions. The unleashing of these multiple processes has resulted in complex inter-caste and gender dynamics and impacted on marriage practices.

On the other end of the spectrum, Dalits, who have been historically, socially, and economically marginalized, even though they constitute 20 per cent of Haryana's population, own a paltry 2 per cent of the land there. With over 8o per cent of Dalits living in rural areas,

${ }^{29}$ A Khap is a cluster of villages united by caste and geography. Khaps or Khap Panchayats are non-elected and non-judicial clan councils, primarily of the sub-caste group of Jats. Each Khap is made up of families belonging to a single clan lineage or gotra that reside in a cluster of neighbouring villages. These are prevalent in Haryana, western Uttar Pradesh, and parts of Rajasthan and are often used to consolidate Jat power and position. Khap Panchayats regulate social behaviour within the caste, within the village, and between caste groups through the use of decrees of social boycotts and other forms of exclusionary punishments. All caste groups, including the Dalits, must toe the line of a particular dominant caste Khap in their region. These all-male patriarchal bodies are used strategically to maintain or re-assert domination and the hegemonic superiority of the Jats in a village or community.

${ }^{30}$ Christope Jaffrelot, Religion, Caste, and Politics in India, New York: Columbia University Press, 2011. 
they are dependent on the three landowning castes for agricultural wage labour as their primary source of livelihood. In post-colonial India, constitutional provisions-in the form of the reservation of 22.5 per cent of government or government-funded educational institutions and state and public sector jobs-were extended to the former Untouchables, thus allowing Dalits to obtain higher education and government jobs that were previously inaccessible to them.

From the 1960s on, the dominant-peasant castes have sought to obtain similar benefits from the reservations of government jobs and admission to educational institutions. As their children secured education, the affirmative action extended to Dalits was viewed by the dominant-peasant castes as their being denied their share of the pie. ${ }^{31}$ In particular, the Jats, who comprise 27 per cent of Haryana's population, continually tried to claim the category of OBC or Other Backward Classes ${ }^{32}$ in Haryana and other neighbouring provinces. ${ }^{33}$ The agrarian crisis in the countryside, compounded by fragmentation of landholdings and declining returns from agriculture, increased the Jats' concern about losing their political, economic, and social clout. Gaining OBC status and, with it, a guarantee of government jobs was viewed as the only solution to maintaining their dominance. In Haryana, the Jats were continually rejected for inclusion in the OBC category as they did not meet the 'backward' criteria. However, their sustained agitation through violent protests in February 2016 finally led the Haryana government to pass a bill including them in this category. ${ }^{34}$

${ }^{31}$ A. R. Kamat, 'The Emerging Situation: A Socio-Structural Analysis', Economic and Political Weekly, Vol. 14, No. 7/8, Annual Number: Class and Caste in India, 1979, pp. 354, 349-354.

32 The Other Backward Classes (OBCs) in Haryana comprise 24 per cent of its population.

${ }^{33}$ The Jats succeeded in getting their caste included in the OBC category in seven provinces: Rajasthan, Delhi, Uttarakhand, Chattisgarh, Uttar Pradesh, Himachal Pradesh, and Madhya Pradesh. However, in March 2015, the Supreme Court of India quashed the decision for their inclusion on the basis that caste alone did not determine reservation, and that socio-economic backwardness was to be the determining criteria. An appeal filed by the central government against this decision too was set aside by the Supreme Court. Amit Chowdhary, 'OBC Status for Jats: SC Quashes Centre's Review Plea', The Times of India, 21 July 2015 , http://timesofindia.indiatimes.com/india/OBC-status-for-Jats-SC-quashes-Centresreview-plea/articleshow/48160573.cms, [accessed 24June 2017].

${ }^{34}$ Express Web Desk, 'Jat Reservation Bill Unanimously Passed in Haryana Assembly', The Indian Express, 30 March 2016, http://indianexpress.com/article/ india/india-news-india/jat-reservation-bill-unanimously-passed-in-vidhan-sabha/, [accessed 24June 2017]. 
Caste-based animosities have become sharply etched in rural areas where Dalits, constituting 21 per cent of Haryana's population, are more politicized and aware. They are unwilling to follow humiliating caste rules about behaviour, dress, segregation of living quarters, movement or employment. ${ }^{35}$ The growing assertiveness of the Dalits against encroachments of village common lands (Shamilat) by the dominant-peasant castes and the former's refusal to adhere to exploitative and demeaning caste practices has led to head-on clashes between the two caste groups, with brutal consequences for the Dalits. Rural class conflict between the landowning castes and Dalit agricultural wage labourers against low agricultural wages and forced free labour (begar) is also manifested through the idiom of caste violence. $^{36}$

Increased urbanization and wider educational and employment opportunities within Haryana have facilitated interaction between young men and women from different castes at schools, colleges, and universities. Partial blurring of caste distinctions in these spaces have also led to love marriages between Dalits and upper castes. Although such marriages are relatively few, these have heightened caste anxiety, primarily among the Jats, that their traditional bastions of power are gradually eroding:

We will not allow for inter-caste marriages here. If it happens, then the caste council will have a meeting and the family will be excommunicated from the community. We have many villages in Haryana: such transgressions will create a big social upheaval here. ${ }^{37}$

The fear of inter-caste marriages creating a 'big social upheaval' is unsurprising as caste is a 'system ... in which differences in the distribution of economic and political power are expressed through ... restrictions'. ${ }^{38}$ With dependence on land and land ownership as major determinants for caste status and hierarchy, maintaining caste endogamy in marriage relations becomes necessary to 'regulate and reproduce ... the hierarchy of social groups' ${ }^{39}$ It is not uncommon to encounter caste council members making such statements as: 'If our

\footnotetext{
${ }^{35}$ Prem Chowdhry, Political Economy of Production and Reproduction: Caste, Custom, and Community in North India, New Delhi: Oxford University Press, 201 1, pp. 383-85.

${ }^{36}$ N. Kumar, 'Dalit Atrocities in Haryana', Institute of Sikh Studies, 2012, http://sikhinstitute.org/oct_2012/7-narinder_kumar.html, [accessed 24June 2017].

${ }^{37}$ Interview: Village women VWC ${ }_{5}$, Rohtak District, Haryana, 13 October 2011.

${ }^{38}$ Suvira Jaiswal, Caste: Origin, Function, and Dimensions of Change, New Delhi: Manohar Publishers, 1998, p. 34 .

${ }^{39}$ Ibid., p. 9.
} 
daughter dares to marry a local Dalit, we will use our belt buckle to teach her a lesson of a lifetime. Such alliances cause schisms (darar) in our society (samaj). ${ }^{40}$ Jat resistance is highest for alliances undertaken by the women with Dalit men as these are interpreted as a Dalit conspiracy to gain control over Jat land wherein Dalit husbands make their Jat wives claim inheritance rights over paternal property: ${ }^{41}$

The woman in inter-caste marriage is the first to come and demand her share of parental property. For example, there's a boy from low caste; he is very shrewd and cunning. He sees an innocent girl from rich upper caste family. He lures her into marriage deliberately with "sweet nothings". Deep inside, he harbours greed for her father's money and land. ${ }^{42}$

Jats have sought the help of non-elected caste councils (Khap Panchayats or Khaps) to have inter-caste marriage treated as serious violations. The Khaps have responded with caste diktats ranging from social ostracism, sanctions against 'erring' low caste groups, or violence against couples. ${ }^{43}$ Dominant caste aversion for inter-caste marriages within Haryana is evident in the statement of Nafe Singh Nain, president of Sarv Jat Khap Mahapanchayat, the supreme council of all Jat caste groups: ${ }^{44}$ 'No way! Caste groups that exist—such as Khati, Chamar, Jats or Brahmins-marriages will take place within the caste group and not intermarry. In Haryana, we will marry only within the caste group. ${ }^{45}$

The Jats have also unleashed a spate of caste violence against Dalits 'to show the community its place', ${ }^{46}$ with collective punishments meted out for individual infractions to cultivate mass fear. Though statistically the number of cases registered under the Scheduled Caste and Scheduled Tribe (Prevention of Atrocities) Act 1989 are fewer than are recorded in other parts of India, 'they are more brutal (as the)

\footnotetext{
${ }^{40}$ Interview: Meher Singh Dahiya, Sisana village, Sonepat District, Haryana, 24 July 2014 .

${ }^{41}$ Deepender Deswall, 'Dalits Flee Haryana Village After Upper Caste Attacks', The Times of India, 16 April 2013, http://timesofindia.indiatimes.com/india/ Dalits-flee-Haryana-village-after-upper-caste-attacks/articleshow/19571623.cms, [accessed 24June 2017].

${ }^{42}$ Interview: Satbir Singh Petwar, Sarpanch (elected village chief), Petwar village, Narnaund, Jind District, Haryana, 24July 2014.

${ }^{43}$ Joshi, 'Dalit Locality Attacked'.

${ }^{44}$ Sarv Jat Khap Maha Panchayat is the caste council of all Jat gots; 300 Khaps constitute the Sarv Jat Khap Panchayat with a sway over 25, Ooo villages across Haryana, Punjab, Western Uttar Pradesh, Rajasthan, and parts of Madhya Pradesh.

${ }^{45}$ Interview: Vinodha Kalan village, Jind District, Haryana, 21 July 2012.

${ }^{46}$ Anil Teltumbde, The Persistence of Caste: The Khairlanji Murders $\mathcal{E}^{\circ}$ India's Hidden Apartheid, London: Zed Books, 2010, p. 73.
} 
message from that one incident is intended to spread to the whole community'. ${ }^{47}$ Dalit women have been deliberately targeted to re-assert caste dominance, to emasculate Dalit men, and to strike fear in the Dalit community there. ${ }^{48}$ There has been a sharp spike in the sexual assault, kidnapping, and murder of Dalit girls and women by Jats in Haryana. ${ }^{49}$ As much as the public face of caste violence is that of men from the dominant castes in Haryana, '[d]ominant caste women [are] complicit ... in the violence that their social order invests in to keep dalits down' ${ }^{50}$ and therefore they are equally culpable as a result of enjoying the privileges and power attendant with their 'upper caste' status.

\section{Transgressing caste across distance}

This backdrop of polarized caste identities, violence against Dalits, and resistance against inter-caste marriages in Haryana is essential to situate caste-transgressive, cross-region marriages. Men rejected in the local marriage market for reasons such as poverty, unemployment, widowhood, physical handicap or alcoholism seek such alliances, unlike those with government jobs, large landholdings or higher education who face no shortage of marriage proposals locally. Marriage migration is not new in India as the custom of patrilocality (residing in the husband's household after marriage), coupled with caste restrictions of clan and village exogamy, creates large flows of female marriage migrants. However, migration distance is largely restricted to a small radius ${ }^{51}$ and marriages are conducted within the same caste due to rules of caste endogamy.

\footnotetext{
${ }^{47}$ Aradhna Wal, 'Silence is not an Option', Tehelka, Vol. 33. No. 10, 17 August 2013, http://www.tehelka.com/silence-is-not-an-option/, [accessed 15 July 2017 ].

${ }^{48}$ AFDR, PUDR and WSS, 'Sexual Assault on Four Girls in Haryana in the Context of Dalit Rights to Common Land: A Status Report on Bhagana', Countercurrents.org, 1 July 2014, http://www.countercurrents.org/pudro10714.htm, [accessed 15 July $2017]$.

${ }^{49}$ Anand Teltumbde, 'Jatland: a Rapists' Republic', Countercurrents, 3 November 2012: http://www.countercurrents.org/teltumbdeo31112.htm, [accessed 15 July $2017]$.

${ }^{50} \mathrm{~V}$. Geetha, 'The Violence of Caste and the Violence in Homes', Agenda: Bias Against Women, Pamela Philipose (ed.), Infochange and Women's Feature Services, 2012, p. 44, http://www.infochangeindia.org/downloads/agenda_25.pdf, [accessed 3 August 2017].

${ }^{51}$ Scott Fulford, 'The Puzzle of Marriage Migration in India', Working Paper No. 820, Boston College Working Papers in Economics, 2013, http://fmwww.bc.edu/ EC-P/wp820.pdf, [accessed 15 July 2017 ].
} 
Though caste and marriage rules conceptually allow for marriage of high-caste men with women lower down the caste hierarchy (Anuloma), in practice, such marriages lack acceptance because of their potential to disrupt the 'status quo in social and economic relationships between two caste categories' ${ }^{52}$ In Haryana, during the colonial period, marriages with local low-caste women by wealthy Jat landowners did occur, but these were on a small scale. ${ }^{53}$ Typically driven by a need to fill labour shortage in families, these alliances, often secondary for men, were frowned upon. Despite the popularity of the adage, 'Whoever marries a Jat becomes a Jatni', the women and their offspring were not accorded equal status as same-caste brides and were made to break off all contact with their families as the "myth of [her] belonging to a higher caste ${ }^{54}$ would be demolished. These alliances were also often challenged by the men's family and extended kin, especially when he died and his share of the property had to pass on to his low-caste widow and heirs. ${ }^{55}$ Unlike then, today the context for such marriages is different as affirmative reservations policies for historically marginalized castes, Dalit political awareness, and 'taboo' love marriages between Dalits and upper castes have posed a threat to the hegemony of the dominant-peasant castes in Haryana. Such fears make the dominant-peasant castes more anxious to assert their dominance, especially in rural areas.

Survey results (see Table 1) reveal that 77.69 per cent or $45^{6}$ men in cross-region marriages are Jats, while brides self-identifying as Scheduled Caste (SG) or Scheduled Tribe (ST) total 35.95 per cent (see Table 2). Survey data from the natal states of Odisha and West Bengal (see Table 3) show that 54.40 per cent of families with daughters in cross-region alliances are either SC or ST. ${ }^{56}$ The evident

${ }^{52}$ Chowdhry, Political Economy of Production and Reproduction, p. 234.

${ }^{53}$ Malcolm Darling, The Punjab Peasant in Prosperity and Debt, Delhi: Oxford University Press, 1925 .

${ }^{54}$ Chowdhry, Political Economy of Production and Reproduction, p. 142.

${ }^{55}$ Ibid.

${ }^{56}$ My research in the two natal regions of Cooch Behar in West Bengal and Balasore in Odisha reveals that parents are not stigmatized in their communities for marrying their daughters to North Indian men. The dominant discourse in conjugal regions that parents sell their daughters is also markedly absent. Natal region villagers look upon such parents pityingly as they are 'forced by poverty (garibir ashahaya) to banish their loved ones so far from them'. Belief in patriarchal notions of gender behaviour and gender norms for women also results in statements such as 'a woman has to be married either way, whether it is here or foreign land (bidesh). So if a man from bidesh wants to marry and doesn't want dowry, who are we to object? The girl's parents 
TABLE 1

Caste of men in cross-region marriages from three blocks of Rohtak District, Haryana.

\begin{tabular}{|c|c|c|c|c|c|c|c|c|}
\hline Caste & Sampla & $\%$ & $\begin{array}{l}\text { Lakhan } \\
\text { Majara }\end{array}$ & $\%$ & Rohtak & $\%$ & $\begin{array}{l}\text { Total } \\
\text { (no.) }\end{array}$ & $\begin{array}{l}\text { Total } \\
\%\end{array}$ \\
\hline Jat. & $15^{0}$ & $81.5^{2}$ & 80 & 79.61 & 226 & $75 \cdot 33$ & $45^{6}$ & 77.69 \\
\hline Ahir & 1 & 0.54 & - & - & - & - & 1 & .17 \\
\hline Chamar & 5 & 2.71 & 8 & 8.73 & 14 & 4.66 & 27 & $4.60^{\circ}$ \\
\hline Pandit & 11 & $5 \cdot 98$ & 2 & 1.94 & - & - & 13 & 2.21 \\
\hline Khati & 1 & 0.54 & 1 & .97 & 7 & 2.33 & 9 & 1.53 \\
\hline Rajput & 4 & 2.17 & 3 & 2.91 & 1 & 0.33 & 8 & 1.36 \\
\hline Valmiki & - & - & 2 & 1.94 & 7 & 2.33 & 9 & 1.53 \\
\hline Pandit & - & - & - & & 21 & 7 & 21 & 3.57 \\
\hline Saini & 3 & 1.63 & - & - & 3 & 1 & 6 & 1.02 \\
\hline Prajapat & 3 & 1.63 & - & - & 1 & 0.33 & 4 & 0.68 \\
\hline Kumhar & - & - & - & - & 1 & 0.33 & 1 & 0.17 \\
\hline Dhanak & 1 & 0.54 & - & - & 2 & 0.66 & 3 & 5.17 \\
\hline Dhobi & 1 & 0.54 & - & - & - & - & 1 & 0.17 \\
\hline Jogi & - & - & - & - & 2 & 0.66 & 2 & 0.34 \\
\hline Luhar & - & - & 4 & 3.88 & 3 & 1 & 7 & 1.20 \\
\hline Bharbhunja & - & - & - & - & 1 & 0.33 & 1 & 0.17 \\
\hline Nai & - & - & - & - & 2 & 0.66 & 2 & 0.34 \\
\hline Teli & - & - & - & - & 1 & 0.33 & 1 & 0.17 \\
\hline Thakur & - & - & - & - & 1 & 0.33 & 1 & 0.17 \\
\hline Dom & - & - & - & - & 2 & 0.66 & 2 & 0.34 \\
\hline Undisclosed & 3 & 1.63 & - & - & 6 & 2 & 9 & 1.53 \\
\hline TOTAL & 184 & 100 & 103 & 100 & 300 & 100 & $5^{87}$ & 100 \\
\hline
\end{tabular}

Source: Author's research study in Rohtak, 2014.

TABLE 2

Caste of cross-region brides in three blocks of Rohtak District, Haryana.

\begin{tabular}{|c|c|c|c|c|c|c|c|c|}
\hline Caste & Sampla & $\%$ & $\begin{array}{l}\text { Lakhan } \\
\text { Majara }\end{array}$ & $\%$ & Rohtak & $\%$ & $\begin{array}{l}\text { Total } \\
\text { (no.) }\end{array}$ & $\begin{array}{l}\text { Total } \\
\%\end{array}$ \\
\hline GC & 63 & 34.24 & 23 & 22.32 & $5^{6}$ & 18.67 & $14^{2}$ & 24.19 \\
\hline OBC & 59 & 32.07 & $17^{*}$ & $16.5^{\mathrm{O}}$ & 82 & $27 \cdot 34$ & $15^{8}$ & 26.91 \\
\hline BC & 3 & 1.64 & - & - & 6 & 2 & 9 & 1.54 \\
\hline SC & 38 & 20.62 & 45 & 43.68 & 110 & $3^{6.66}$ & 193 & 32.87 \\
\hline ST & 4 & 2.17 & 5 & 4.86 & 9 & 3 & 21 & 3.57 \\
\hline Muslim & 5 & 2.72 & 5 & 4.86 & 5 & 1.66 & 15 & 2.55 \\
\hline Sikh & 1 & 0.55 & 2 & 1.96 & - & - & 3 & $0.5^{1}$ \\
\hline Christian & - & - & 1 & 0.98 & 2 & 0.67 & $\begin{array}{l}5 \\
3\end{array}$ & $0.5^{1}$ \\
\hline Buddhist & 1 & 0.55 & - & - & - & - & 1 & 0.17 \\
\hline Undisclosed & 10 & $5 \cdot 44$ & 5 & 4.86 & $3^{0}$ & 10 & 45 & 7.66 \\
\hline TOTAL & 184 & 100 & 103 & 100 & 300 & 100 & $5^{87}$ & 100 \\
\hline
\end{tabular}

Source: Author's research study in Rohtak, 2014.

- In Sampla Block, of the 59 OBC brides, 44 are from the Jat caste.

*In Lakhan Majara Block, of the 17 OBC brides, 14 are from the Jat caste.

- In Rohtak Block, of the 82 OBC brides, 77 are from the Jat caste. 
TABLE 3

Caste/religion of cross-region brides' natal survey.

\begin{tabular}{|c|c|c|c|c|}
\hline Caste & $\begin{array}{l}\text { Baleshwar } \\
\text { (no.) }\end{array}$ & $\begin{array}{l}\text { Cooch } \\
\text { Behar (no.) }\end{array}$ & $\begin{array}{l}\text { Total } \\
\text { (no.) }\end{array}$ & $\begin{array}{l}\text { Total } \\
\%\end{array}$ \\
\hline SC-Hindu & 26 & 78 & 104 & $3^{8.80}$ \\
\hline ST-Hindu & 1 & - & 1 & 1.49 \\
\hline GC-Hindu & 8 & 16 & 24 & 11.95 \\
\hline OBC Hindu & $3^{1}$ & 9 & 40 & $4^{6.27}$ \\
\hline Muslim OBC & - & 14 & 14 & \\
\hline Muslim GC & 1 & 9 & 10 & 1.49 \\
\hline TOTAL & 67 & 126 & 193 & 100 \\
\hline
\end{tabular}

Source: Author's research study in Odisha, 2011 , and West Bengal, 2014.

inter-caste nature of these alliances poses a dilemma as trenchant opposition to local inter-caste alliances and perpetration of caste atrocities against local Dalits is overwhelmingly committed by Jats. ${ }^{57}$

Can it be presumed that caste discrimination is exhibited by conjugal kin or caste members only against local Dalits with no spillover whatsoever of prejudice or discriminatory caste behaviour against Dalit cross-region brides? The desperation of men to seek wives from within their own jati before going to other states belies this: 'A man first tries to get a match from within his caste and community. His honour is not lost then. However, when it's not possible, his helplessness forces him to seek a bride from elsewhere. ${ }^{58}$

Ostensibly, the female shortage caused by sex selection within their caste emerges as the men's primary motive for obtaining 'low-caste' wives from distant parts of India. The compulsion to do this and risk losing highly valued family and caste honour through

have to do the right thing and marry her off.' Interview: Villager VMN $n$, Balasore District, Odisha, 28 November 2011. At the same time, when some of these women do visit their natal homes, better dressed and with gifts for the family, they give the appearance of being better off. Such visible markers of upward mobility help to dispel misgivings about such alliances. Natal communities also display genuine ignorance about caste groups or the ranking of the men's jatis in the caste hierarchy in conjugal regions. This might also act as a contributory factor to the non-stigmatization.

${ }^{57}$ Teltumbde, 'Jat Republic'; WSS, Speak! The Truth is Still Alive: Land, Caste, and Sexual Violence Against Dalit Girls and Women in Haryana, Women Against Sexual Repression and State Violence, New Delhi, Special Report, December 2014, https://wssnet.files.wordpress.com/2014/o7/wss-haryana-report-compiled.pdf, [accessed 10 September 2017].

${ }^{58}$ Interview: Husband's brother HB $n$ 1, Rohtak District, Haryana, 9 October 2011. 
such 'inappropriate' actions ${ }^{59}$ is necessitated primarily because the daughter-in-law does the bulk of the agricultural work, tends the cattle, and manages the household among the Jats and other landowning castes of Haryana. It is also necessary to realize that this compulsion occurs only when men are unable to fend for themselves, that is, their mothers cannot do household chores as they are too old or infirm or the wives of other brothers refuse to cook for them. Despite awareness of caste ostracism that is attendant upon intercaste marriages, the compulsion to do so is summed up by a man commenting that, 'I will have my independent household (ghar ka tala khulega aur chulha chalega). I am tired of depending on others for food and other daily needs. My lineage will continue too with the birth of my children. ${ }^{60}$

Additionally, the economic necessity for the 'free and unpaid' labour of female family members in household subsistence farming and agricultural wage work is another big incentive to transgress caste rules regarding marriage. When questioned about the response of the community towards caste transgression in cross-region marriage, men typically respond with 'tab ki tab dekha javega' or 'we will cross that bridge when it comes'. ${ }^{61}$ This false bravado about caste ostracism is also fuelled by a hope that their family will be an exception to the rule and be spared the ignominy of bringing home a low-caste, cross-region bride.

The question then arises: if honour is lost with caste-transgressive alliances, why do the locally rejected Jat males not undertake local marriages from supposedly 'female-rich' Dalit castes? Then they would not have to incur travel expenses or mediator fees, nor would local, low-caste brides require training into local cultural mores or work ethics—adjustment problems commonly encountered by cross-region brides.

The men first aspire to find brides from outside their customary marriage pools in the neighbouring provinces of Himachal Pradesh and Uttarakhand as the generally fair complexion of such women allows easier manufacture of lies about their high-caste status. In the absence of securing supposedly 'culturally and caste akin' brides from

\footnotetext{
${ }^{59}$ Uma Chakravarti, 'From Fathers to Husbands: Of Love, Death and Marriage in North India', Honor: Crimes, Paradigms, and Violence Against Women, L. Welchman and S. Hossian (eds), London: Zed Books, 2005, pp. 310, 308-33.

${ }^{60}$ Interview: Unmarried male UM $n$ 1, Rohtak District, Haryana, 9 October 2011.

${ }^{61}$ Ibid.
} 
these parts, the men widen their search and often make requests for brides who are similarly situated to them in the caste order. Failing to do so, they settle for anyone who agrees to marry them as affirmed by a mother-in-law of a cross-region bride: 'We lost many years in trying to find a bride from our caste pool (apni jaati ke maare itne saal maar diye). We are no longer worried about matching caste. I am too old now to be doing things. ${ }^{62}$

The largest numbers of these marriages are arranged by crossregion brides who tap into their natal social, kin, and caste networks back home to locate women who can potentially become cross-region brides. Consequently, certain caste categories are more reproduced than others in cross-region marriages. Potential grooms also do not insist on caste equals as they often have a fuzzy understanding of natal-region caste groups or ranking in caste hierarchy due to 'alien' sounding jati and got names, and the absence of exact caste equivalents to facilitate comparisons.

This point about the unclear ranking of women's caste makes such marriages a preferred option for Jats and other dominant-peasant castes with several spinoffs. For one, such alliances do not pose a challenge to existing unequal caste hierarchies in the conjugal regions as the vast geographical distance between the two regions restricts social verification about the women's caste identity. Second, sourcing local, low-caste women as wives could be interpreted as tacit approval of alliances between their own women with Dalit men. With women acquiring equal inheritance rights over paternal property since $195^{6,}{ }^{63}$ perceived threats to caste dominance of the Jats asserted through patrilineal inheritance in landholdings are seen in the 'introduction of a non-caste outsider [groom] who can and may claim property on behalf of his wife'. ${ }^{64}$ Long-distance alliances thus allow the community to maintain the status quo in opposing their women's marriage with Dalit men. It also lets the family maintain a stoic public façade and vociferously claim that the brides are not of 'low-caste' stock by hiding or fabricating their identities. One Jat mother-in-law stated:

\footnotetext{
${ }^{62}$ Interview: Mother-in-law of a cross-region bride MILn2, Rohtak District, Haryana, 7 October 2011.

${ }^{63}$ The Hindu Inheritance Act of $195^{6}$ granted equality to women in inheritance rights.

${ }^{64}$ Chowdhry, Political Economy of Production and Reproduction, p. 264.
} 
If we bring a woman from elsewhere, we reassure our kin and villagers that she belongs to same caste as the Jats, Thakurs or Gujars ${ }^{65}$ over there. However, if we marry a low-caste woman from this region, the truth will come out in a moment that the bride belongs to a Scheduled Caste- that she is a Chamar ${ }^{66}$ or a Churhi. ${ }^{67}$ Objections will be raised about such an alliance. ${ }^{68}$

Families recognize that the 'truth' that a similar caste-transgressive alliance, if undertaken locally, cannot be hidden. A husband explains that 'the family can be ostracized by the community or threatened with excommunication if her caste status is in doubt'. ${ }^{69}$ With the threat of social ostracism or excommunication hanging over them, the family's ability to reassure the community is made easier 'if someone marries a woman from another region as no one is wiser about the caste of the bride. It is an unknown. ${ }^{70}$ Notwithstanding these cautionary pretences, it appears that 'families that get such brides are shunned by both the extended family and the community (kin group). Secondly, relations get broken because of her unknown caste status. ${ }^{71}$ Given this, it is surprising to have Mishra, who has worked in a mere five villages in the Rohtak District of Haryana, contend that the intercaste nature of such alliances is 'accepted as "normal' ${ }^{72}$ and that such alliances do not 'affect caste hierarchy' or 'local caste authority' since these are driven by circumstances of sex imbalance. On the other hand, Kaur's study on brides in Uttar Pradesh notes that if the families 'are not themselves from a Dalit community, they ask for a "clean caste" bride', ${ }^{74}$ thus underscoring anxieties about the latent desire to maintain caste purity.

${ }^{65}$ Thakurs are upper caste and Gujars are similarly ranked to the Jats, that is, they are a dominant-peasant caste group belonging to the Shudra varna.

${ }^{66}$ Chamars were traditionally leather workers and tanners. Dealing with carcasses of animals made them polluted and hence banished them to the category of Untouchable castes within the Brahmanical Hindu caste stratification.

${ }^{67}$ 'Churhi' alludes to a female of the Churha caste, ranked as 'Untouchable'. Their traditional occupation was sweeping and removing waste, hence the 'dirty' or 'polluting' stigma attached to their group.

${ }^{68}$ Interview: Mother-in-law MIL $n$ 17, Rohtak District, Haryana, 23 September 2014.

${ }^{69}$ Interview: Husband $\mathrm{HH} n 6$, Rohtak District, Haryana, 9 October 2011.

${ }^{70}$ Focus group: Jat men FGJM $n$ 1, Rohtak District, Haryana, 13 October 2011.

${ }^{71}$ Ibid.

${ }^{72}$ Mishra, 'Sex Ratios', p. 71.

${ }^{73}$ Ibid., p. 74 .

${ }^{74}$ Ravinder Kaur, 'Marriage and Migration: Citizenship and Marital Experience in Cross-border Marriages between Uttar Pradesh, West Bengal and Bangladesh', Economic and Political Weekly, Vol. 47, No. 43, 201 2, pp. 84, 78-89. 
Crucially, in-coming Dalit brides either voluntarily 'hide their real caste' or are 'advised"75 to do so by conjugal family. This is hardly surprising as Dalits face systemic and structural discrimination because of their low-caste status and are subjected to daily humiliation, degradation, and exploitation through caste-enforced codes governing dress, behaviour, housing, employment, and access to services and resources. ${ }^{76}$ Dalit women suffer more due to the intersection of caste with gender and patriarchy. This makes many Dalit brides mask or deny their 'low-caste' background. During the survey, a few brides $(n=12)$ acknowledged calling up their natal families to ask which 'high'-caste name they could adopt for themselves for the research. Others stated they had deliberately chosen to self-identify as Jats despite hailing from West Bengal, Jharkhand, Odisha, Tripura, Maharashtra or Assam. For Sampla Block, 14 of the 44 brides who self-identified as Jats came from these states; in Lakhan Majara, it was 4 of 17; and in Rohtak Block, the number was 29 of 77 (see Table 2 for a detailed breakdown of the cross-region brides' castes). This is significant as each jati and got has spatial limits-Jats are confined to North Indian states of Haryana, Punjab, Rajasthan, and parts of Madhya Pradesh and Uttar Pradesh.

Fictive justification for these non-customary marriages is also made on the grounds that the two jatis are similar and on the same level, even though they are geographically distant. During interviews, conjugal family members often asserted that brides belonged to the Jat or Yadav caste in West Bengal or Odisha, the only difference being that these castes had a different name there. Historically, when one group of a caste sub-group adopted a different economic activity with consequent changed social status and power, it eventually would lead to a rupture in 'social interaction with its other caste constituents'. ${ }^{77}$ The contention that caste rules are not breached by entering into non-endogamous alliances is also negated as the two jatis (conjugal and natal), in a majority of cases, come from different socio-economic strata and occupations. According to Kosambi, migration of a got to another region altered its ranking in the caste hierarchy and if the

\footnotetext{
${ }^{75}$ Interview: Mother-in-law MIL $n$ 17, Rohtak District, Haryana, 23 September 2014.

${ }^{76}$ G. Shah, H. Mander, S. Thorat, S. Deshpande, and A. Baviskar, Untouchability in Rural India, New Delhi: Sage Publications, 2006, p. 216.

${ }^{77}$ Jaiswal, Caste, p. 5 .
} 
differentiation persisted, it regarded itself as a different caste and no longer intermarried within the sub-caste. ${ }^{78}$

Caste councils (Khap Panchayats) also offer tacit approval of such marriages because these alliances do not directly challenge existing, local, unequal caste hierarchies. Nafe Singh Nain, president of Sarv Jat Khap Mahapanchayat, states: 'There are many bachelors in every village who go and bring wives. They bring a woman from some other caste from another region, but within the village, we won't have marriage with different jatis. ${ }^{79}$ Though admitting that such marriages 'help the men survive', he is quick to assert that caste taboos about purity and pollution enforced through inter-dining are maintained as 'no one drinks water from such households' ${ }^{80}$

The contradictions contained in caste elders offering tacit approval to inter-caste, cross-region alliances while simultaneously upholding caste rules on inter-caste marriages can be best explained by a local proverb: 'Without a wife, both the home and the field are ruined' (lugai ke bina na ghar ka, na khet ka kaam chaale). Caste elders and villagers alike acknowledge the centrality of women's labour in the agrarian economy and in animal husbandry in Haryana. Historically too, British colonial administrators recognized that 'marriage and possession of a wife ... [was an] "economic necessity" "81 and thus, despite pressure from dominant-peasant caste elites to outlaw intercaste marriages in Haryana, chose to disregard such caste infractions from a purely revenue-generation perspective. The colonial rulers argued that "[a]n akela adami (single man) was not expected to perform well agriculturally and a widower was considered "half-paralysed". The sooner he married the better it was for the economy of the state and for payment of government dues. ${ }^{82}$

Cross-region marriage, in this light, has to be regarded as a shrewd and well-thought-out tactic for five reasons. It allows families to circumvent caste rules on inter-caste marriages and to avoid caste sanctions. It permits caste councils to sidestep the quagmire of

${ }^{78}$ D. D. Kosambi, The Culture and Civilization of India in Historical Outline, New Delhi: Vikas Publishing House, 1997, p. 15 .

${ }^{79}$ Interview: Vinodha Kalan village, Jind District, Haryana, 21 July 2012.

${ }^{80}$ Ibid.

${ }^{81}$ Prem Chowdhry, 'Fluctuating Fortunes of Wives: Creeping Rigidity in Inter-caste Marriages in the Colonial Period', The Indian Historical Review, Vol. 34, No.1, 2007 , pp. $221,210-243$.

${ }^{82}$ Darling, Punjab Peasantry in Prosperity and Debt, quoted in Chowdhry, 'Fluctuating Fortunes', p. 221. 
inter-caste alliances by simply stating that the caste identity of these women is 'ambiguous' or that the women come from similarly placed Jat caste groups that are labelled differently in another language and region. It lets villagers and kin networks use the brides' fabricated caste identities as flimsy excuses to turn a blind eye to blatant caste infractions of these alliances. It enables families with cross-region brides to use their 'free and unpaid' labour in household subsistence farming and cattle rearing to sustain the household economy rather than being reduced to destitution by having to hire wage labour. Most importantly, it allows the upper castes continued legitimacy to maintain local unequal hierarchies of caste relations by opposing inter-caste alliances on home turf.

\section{Caste dynamics within the intimacy of home}

On the surface, caste fabrications by the brides or their families seemingly paper over caste rifts. But do such excuses permit brides to be accepted as caste equals? Does the 'cultural oppression' and hierarchies of domination and discriminations that Dalits experience get similarly reproduced within their new families? In the classical patriarchal set-up of patrilineal and patrilocal households, marriage truncates all incoming women's rights; they become 'effectively dispossessed individuals'. ${ }^{83}$ Does the added dimension of caste heighten the subordination of cross-region brides in conjugal homes?

Before a detailed analysis of the condition of Dalit cross-region brides in conjugal homes is undertaken, it is necessary to briefly outline the compromised bargaining ability of all cross-region brides. In classical patriarchy, new daughters-in-law enter households with truncated rights and an inferior status within the family hierarchy. ${ }^{84}$ For cross-region brides, the stress of adjusting to new families and their lowered position in the family power hierarchy as a daughter-inlaw is further magnified. They are torn from all their familiar cultural and social moorings and have to contend with an unfamiliar language and physical environment, with different ways of cooking, eating, and dressing, with alien cultural norms and customs governing behaviour of brides, and with lack of familiarity with chores.

${ }^{83}$ Denise Kandiyoti, 'Bargaining with Patriarchy', Gender and Society, Special Issue to Honor Jessie Bernard, Vol. 2, No. 3, September 1988, pp. 279, 274-290.

${ }^{84}$ Ibid. 
In comparison to the local brides, the cross-region brides fare poorly in household bargaining outcomes because of their poor fall-back position. ${ }^{85}$ Factors such as the mode of their marriage, that is, whether they are trafficked, ${ }^{86}$ coerced or married with the consent of of their parents; the fee paid by the grooms to marriage agents; the distance between natal and conjugal regions; and their perceived internal other' or low-caste status combine to alter relations of dominance and subordination, patriarchal constraints, and bargaining power of these brides. Weak or absent 'social support systems ${ }^{87}$ and the notion that they are 'bought' due to the fee paid to the mediators further compromises their bargaining ability and results in greater off-loading of household and agricultural chores on them.

Cross-region brides compare their existence to incarceration in prison: they face a higher degree of control and surveillance over their movements or ability to freely associate with other women in conjugal villages. ${ }^{88}$ They are usually not allowed to visit their natal families in the early years for fear that they might not return. Additionally, the crisis in masculinity of their husbands caused by their rejection in local marriage markets affects the men's intimate relationships with their wives. To overcome the bruising of the male ego, such husbands undertake acts of masculine compensation involving stricter controls and greater physical violence against the cross-region brides. The degree and intensity of controls are higher for brides sourced from traffickers. $^{89}$

${ }^{85}$ Bina Agarwal, "Bargaining” and Gender Relations: Within and Beyond the Household', Feminist Economics, Vol. 3, No. 1, 1997, pp. 1-51.

${ }^{86}$ Unlike Rohtak, instances of bride trafficking abounded in other research areas of Alwar and Jhunjhunu in Rajasthan and Mewat in Haryana where a number of brides spoke openly about their trafficking, coercion or re-selling, and villagers also pointed out specific instances of bride-trafficking. In Rohtak District, only one conjugal family member acknowledged dealing with a trafficker and 'buying' a bride. In all other instances, the payment of mediator fees was interpreted as the 'purchase' of these brides from their parents by the locals, a fact vehemently rejected by all cross-region brides in Rohtak District. The subject of polyandry and sexual abuse of cross-region brides by male members of a household is a very sensitive one. Though rumours abound, no focus group or interviewees actually pinpointed a bride who had been abused in this way. This is not to say that it does not occur. A more intimate and long duration research with embedded participant observation might allow some brides to open up and share such narratives.

${ }^{87}$ Agarwal, "Bargaining" and Gender Relations'.

${ }^{88}$ Interview: Hindu bride $\mathrm{BH}_{5}$, Rohtak District, Haryana, 8 October 2011.

${ }^{89}$ Focus group: Hindu brides FGB $n$ 1, Rohtak District, Haryana, 9 October 2011. 
In the case of Dalit cross-region brides, caste prejudice and caste exclusionary practices worsen their intra-household and intragender bargaining outcomes. It creates another sub-category of marginalization that cross-region brides hold within the conjugal households and communities. I contend below that conjugal families are not shorn of their caste-prejudiced beliefs and behaviours during interactions with Dalit brides.

Caste ideology that legitimizes caste violence, discrimination, and exclusionary behaviours is both internalized and normalized by upper castes. It does not operate on a simplistic principle of caste discrimination that can be deployed unconnectedly vis-à-vis local Dalits but not Dalit cross-region brides. During interviews, although conjugal family members employed politically correct statements such as 'all humans are equal' (sab manush ek hain); 'we do not believe in caste discrimination like untouchability' (hum chua choot main vishwas nahin rakhte) or 'caste discrimination is something of the past' (yeh sab batein purani hain),${ }^{90}$ on being questioned whether this rhetoric was similarly applicable to local low-caste groups, their 'broadminded' façade crumbled with unequivocal statements that 'It is a different matter with them' (unki alag baat hain). ${ }^{91}$

The continual emphasis of families with Dalit cross-region brides that such brides are not low caste also allows the families to continue exercising caste prejudice against local Dalits. They have much to lose socially if they are perceived as being lax in practising caste discriminatory practices vis-à-vis local Dalits. A father-in-law, on being asked if having a Dalit daughter-in-law made any difference to his attitude towards local Dalits, quoted a local proverb, 'What caste can a woman have' (beeran ki kai jaat nahin) to emphasize the fluidity of a woman's caste and its dependence on the caste or religion of the man she marries. ${ }^{92}$ Having a Dalit daughter-in-law did not change his views on local caste hierarchies, his stance on maintaining Jat's social domination and authority locally through authority or violence, nor his practice of caste discrimination against local Dalits. In general, the façade of these brides having higher caste status also prevents local Dalits from acknowledging contradictions in the dominant-peasant

\footnotetext{
${ }^{90}$ Interviews: Husband $\mathrm{HH} n$ 9, Rohtak District, Haryana, 12 April 2011 ; Fatherin-law FILn 1, Rohtak District, Haryana, 7 October 2011.

${ }^{91}$ Interview: Husband's sister HS $n$ 1, Rohtak District, Haryana, 13 October 2011.

${ }^{92}$ Gyanendra Pandey, Remembering Partition: Violence, Nationalism, and History in India, Cambridge: Cambridge University Press, 2001, p. 165 .
} 
caste stance of opposing local inter-caste marriages and on enforcing caste discrimination based on pollution through food and drink.

Not all cross-region brides experience caste violence in the form of exclusion, discrimination, and caste slurs. The gamut and degree of caste violence vary and are determined by various factors, including the necessity of having a female perform domestic chores within the household, the region from which the bride is sourced, and the economic clout of the conjugal family within the community. That a significant number of the interviewed brides $(n=24)$, during one-onone interviews, brought up 'caste concerns', a code word for castebased discrimination, indicates its pervasiveness. Concern for human rights violation makes it imperative to take such testimonials seriously and not dismiss them on the grounds that because experiences of caste discrimination are not shared by all, they are not worthy of consideration. ${ }^{93}$ Such contentions are especially problematic given the contemporary Indian reality. A 2014 survey found that over 27 per cent of Indians practise Untouchability and over 30 per cent do not allow a Scheduled Caste person to enter their kitchen or handle utensils, with the numbers being higher in rural than urban areas. ${ }^{94}$ This is significant as inter-caste relations and caste hierarchies are also defined through rules governing food preparation and commensality.

Anupama Rao notes that the body acts as the 'experiential site' for 'intimate practices' of caste violence to be enacted against it, ${ }^{95}$ and which makes systemic caste violence invisible. In this case, everyday interactions within the family and kin group and with village women allow 'intimate practices of prejudice' to be performed against brides whose caste identity is perceived to be lower than that of the group into which she is married. The most striking aspect of such castebased oppression is that it takes place mostly within the four walls of the house, shared both by those perpetrating the violence and the one at the receiving end of it.

\footnotetext{
${ }^{93}$ Mishra, 'Sex Ratios'.

${ }^{94}$ Seema Chisti, 'One in Four Indians Admit to Practising Untouchability', Indian Express, 29 November 2014, http://indianexpress.com/ article/india/india-others/one-in-four-indians-admit-to-practising-untouchabilitybiggest-caste-survey/, [accessed 15 July 2017 ].

${ }_{95}$ Anupama Rao, 'Violence and Humanity or, Vulnerability as Political Subjectivity', Social Research, Special Issue on 'Body and the State', Vol. 78, No. 2, Summer 2011 , pp. 625, 607-632.
} 
In a patrivirilocal family set-up, often the mother-in-law weighs her strategies and makes an opportunistic 'patriarchal bargain'96 with caste, wherein she pragmatically ensures that the new bride's life is not made hellish by other women in the household. This by no means implies she does not exhibit caste prejudice. The necessity of having a 'worker' acquiesce to her commands and do her bidding warrants that a veneer of caste 'assimilation' is maintained to prevent the bride from outright rebellion. Yet within the intimacy of relations, the Dalit bride is subject to varied disciplinary mechanisms continually reminding her not to overstep boundaries.

Sometimes, overt caste discrimination is exercised by establishing a separate kitchen or hearth for the bride or by not allowing her to perform prayers at the family altar. The resistance of the wives of other brothers to treat such brides as 'caste equal' is often displayed by their refusal to share intimate space or sit alongside her. A bride from Maharashtra stated that despite being married for six years, she had to maintain a separate cooking area and her mother-in-law refused to eat food cooked by her. ${ }^{97}$ Fears of low-caste brides sullying the family's caste status also inhibit families from taking them to social events. ${ }^{98}$ Kaur, in her study of cross-region brides in Uttar Pradesh, similarly notes that brides of Bengali descent face 'incompleteness of acceptance' from their husband's relatives. ${ }^{99}$

Caste slurs like 'Churhan' or 'Chamaran'100 are also deployed as verbal weapons to assert caste supremacy and show brides their proper 'designation' within the family hierarchy $(n=19)$. Here, caste epithets, as coded texts carrying the force of historical discrimination and caste violence of upper castes, are harnessed to teach Dalit women not to overstep boundaries and to continually keep them suspended in a subservient state. ${ }^{101}$ The use of language as a discursive tool to subjugate and subdue certain categories of people is neither new nor innocent. A 2014 study on systemic caste violence by upper castes against Dalit women spanning four states in India reveals that '(d)alit

${ }^{96}$ Kandiyoti, 'Bargaining with Patriarchy'.

${ }^{97}$ Interview: Bride $\mathrm{BH}_{5}$, Rohtak District, Haryana, 8 October 2011.

${ }^{98}$ Interview: Bride $\mathrm{BH} n$ 1, Rohtak District, Haryana, April 2011.

${ }^{99}$ Kaur, 'Marriage and Migration', p. 83 .

100 'Churhan' or 'Chamaran' alludes here to females from the 'Churha' or 'Chamar' caste groups, both of which are considered Untouchables by caste Hindus. These terms are considered pejorative in connotation.

${ }^{101}$ S.J. Irudayam, J.P. Mangubhai, and J.G. Lee, Dalit Women Speak Out: Caste, Class and Gender Violence in India, New Delhi: Zubaan Publications, 2014, pp. 103-109. 
caste names, when used as a form of address, function as contemptuous terms of abuse'. ${ }^{102}$ The invisibility of such caste violence makes it harder to prove the damage caused to the psyche of marginalized Dalits. In India, caste slurs are punishable under the Scheduled Castes and Scheduled Tribes (Prevention of Atrocities) Act and Rules 1989. In addition, the Supreme Court of India, in a 2008 judgment, too noted that caste slurs were 'often used by people belonging to the so-called upper castes or even by OBC as a word of insult, abuse or derision'. ${ }^{103}$ Notwithstanding, Mishra's paper, while noting the slur of 'Churhi' used by a mother-in-law against her Valmiki ${ }^{104}$ (Dalit) daughter-in-law as caste discrimination, downplays its implicit caste violence by citing the case of a husband reassuring his wife that his mother would cease using such slurs if she gave birth to a son. ${ }^{105}$ In this case, there is a promise of inclusion of the bride, on terms set by the upper caste and to be granted at their behest-not something to be obtained naturally as local brides would experience.

\section{Caste dynamics within kin networks and village}

On the surface, village or kin women are quick to assert that they do not display caste discrimination towards cross-region brides and that they treat them as equals. Focus groups of village women assert that 'they are having a good time here' (bahut mauj mein rawen hain) 106 or 'they are content here and do not have any problems here' (khush rawen, unhe kisi baat ki taqleef na sain). ${ }^{107}$ Often such statements allude to lack of wants rather than absence of caste discrimination. However, internalized notions of caste hierarchy and ritual taboos on association are tested when communal space has to be shared with these brides as caste equals, as revealed by a focus group:

She is not from our caste. Who knows from where they have sourced her? The compulsion to have someone run the house forces them to seek a wife from

${ }^{102}$ Ibid., p. 107 .

${ }^{103}$ S.K. Singh, 'Calling an SC "Chamar" Offensive, Punishable says Apex Court', Economic Times, 20 August 2008, http://articles.economictimes.indiatimes.com/ 2008-o8-20/news/28488600_1_upper-castes-insult-chamar, [accessed 15 July 2017 ]

${ }^{104}$ Valmiki is another Dalit caste group.

${ }^{105}$ Mishra, 'Sex Ratios', p. 75 .

${ }^{106}$ Focus group: Village women FGWn2, Rohtak District, Haryana, 9 October 2011.

${ }^{107}$ Focus group: Village women FGWn4, Rohtak District, Haryana, 14 October 2011 . 
another caste. She is not from the same caste or economic class as us. We don't easily associate with her. ${ }^{108}$

The denial or withdrawal of friendship is a covert mechanism through which caste hierarchies are maintained while allowing caste and kin women to maintain an overt mask of caste geniality with the brides and their families. Nonetheless, the stigmatized brides, acutely attuned to detecting caste humiliations and discriminations, are able to see pretences for what they really are. This awareness is displayed in a Dalit bride's comment: 'They don't insult us openly. Instead, they taunt us about our caste behind our back. It hurts us-we are aware that they do it. We are helpless and cannot respond back. ${ }^{\text {,109 }}$ Upper caste village women intentionally use caste epithets to assert their hegemonic caste superiority over the brides, especially during altercations over resource sharing of water or firewood. For example, one acknowledged: 'We do it deliberately. For we know it will hurt them. Calling them Churhi or Chamaran rankles them up.' ${ }^{110}$

Apart from endogamy, inter-caste relations and caste hierarchies are defined through food as rules governing its preparation and commensality are crucial to maintain hierarchies of exclusion and inclusion or purity and pollution. With the preparation of food falling into their domain, women come to play a central role in keeping intact the 'purity' of their caste group. A few brides $(n=3)$ noted their exclusion from weddings and other life-cycle ceremonies of kin members because they are viewed as 'low caste' (neech jaat) and hence are not allowed to participate in food preparation during such events. Brides also find that ritual notions of caste pollution through food and drink are invoked in everyday encounters to remind them of their ritually taboo status and to enforce boundaries of association, thus making them continually experience being a 'stigmatized body', ${ }^{111}$ one whose low-caste identity cannot be erased by marriage to a perceived upper caste man.

Caste oppression is intensified by colourism or skin-tone prejudice practised by conjugal families and communities against dark-skinned,

\footnotetext{
${ }^{108}$ Focus group: Jat women FGJWn 1. Rohtak District, Haryana, 8 October 2011.

${ }^{109}$ Interview: Bride BH $n$ 1 7, Rohtak District, Haryana, 11 October 201 1. A similar statement was made in Interview: Bride $\mathrm{BH} n 1$ o, Rohtak District, Haryana, 10 October 2011 .

${ }^{110}$ Focus group: Village women FGWn4, Rohtak District, Haryana, 13 October 2011.

${ }^{111}$ Rao, 'Violence and Humanity'.
} 
cross-region brides. In the absence of other ways to verify the caste of cross-region brides, colourism or pigmentocracy is used by people in conjugal regions to interpret the caste rank of these brides based on the amount of melanin their skin contains. For instance, two interviewees explained that caste taboos are rarely invoked for women from the states of Himachal Pradesh or Uttarakhand on grounds that 'they share the same cultural values and beliefs' 112 and 'don't belong to low caste as they are "gori" (fair complexioned) and "saaf-suthri" (neat and tidy)'. ${ }^{113}$ With the historical linkage of dark skin with low-caste status and lighter skin with upper caste Hindus, ${ }^{114}$ the non-discrimination of women from Himachal Pradesh or Uttarakhand occurs largely because their skin-tone, even if these brides come from Dalit or Tribal families, is more in line with the dominant colour discourse conflating whiteness with higher caste status.

Similarly, the social capital of light skin and its association with higher caste identity appears to privilege lighter-hued Dalit crossregion brides solely because it allows easier fabrication of higher caste genealogy for them, unlike for darker-complexioned women from similar Dalit caste background. A Jat man with a dark-skinned crossregion bride elaborates:

If there are two women from outside and one is fair and the other dark, the common assumption in Haryana's samaj (society) is that fair-skinned people are from higher castes. Such women are assumed to come from well-to-do families and higher castes. The dark-skinned women are called Churhan or Chamaran. They are immediately understood as having low caste origins. ${ }^{115}$

Colourism thus reinforces caste bias by adding skin as a visible marker of otherness. Consequently, a majority of women from Odisha, West Bengal or Assam who have darker complexions are visibly stigmatized as 'neech jaat' (low caste) even if they are not Dalits. Their dark skin impedes their acceptance into conjugal communities largely due to the association of dark skin with low-caste status and undesired ethnicity, as made evident in an interview with a darker-hued bride from West Bengal who stated: 'The people here think that because I am dark in colour, I belong to a low caste. They make fun of me and

${ }^{112}$ Focus group: Village women FGJW $n$ 1, Rohtak District, 8 October 2011.

${ }^{113}$ Interview: Village woman VWCn 2, Rohtak District, 9 October 2011.

${ }^{114}$ Varsha Ayyar and Lalit Khandare, 'Mapping Colour and Caste Discrimination in Indian Society', The Melanin Millennium: Skin Colour as 2 Ist Century International Discourse, R.E. Hall (ed.), London: Springer, 2013, pp. 71-95.

${ }^{115}$ Interview: Hindu husband $\mathrm{HH}_{5}$, Rohtak District, Haryana, 8 October 2011. 
call me "a low caste woman" (neech jaat ki). ${ }^{116}$ For dark-skinned Dalit cross-region brides, the intersection of gender, caste, and ethnicity with colourism ends up creating and reinforcing multiple oppressions.

Given this, the multiply 'internally othered' cross-region brides contradict the majoritarian view that they live in 'mauj' or luxury. They do, however, admit that these marriages offer them upward mobility solely from an economic perspective. Despite a majority being married to men who are poor, landless, or underemployed, these brides acknowledge that, from the food security angle, they are better off than before. But they vehemently contest the claim that they acquire caste upward mobility through marriage to men higher up in caste hierarchy. The perniciousness of caste ideology that legitimizes the exercise of quotidian caste prejudice and caste exclusionary behaviours has many cross-region brides agreeing with one woman's assertion:

We were better off in our own region. At least then I wouldn't have to continually hear insulting remarks about my caste or my ethnicity. The folks here call us low caste all the time. If I had got married back home, I wouldn't have to face such taunts then. ${ }^{117}$

In this light, it is necessary to acknowledge variations in experiences of cross-region brides and their access to power within conjugal homes instead of 'universally grouping' them into an 'already constituted, coherent group with identical interest and desires, regardless of ... contradictions' ${ }^{118}$ or assuming the sameness of their oppression from patriarchy. These examples contradict Kaur's contention that the bride's caste identity is 'subsumed' into that of her husband. ${ }^{119}$ Despite the prevailing local contention that 'a woman who marries a Jat becomes a Jatni', evidently, for some brides, this 'embrace' into the caste family does not erase their Dalit origins nor make accommodations about discriminatory practices. Problematically, such contentions and village women's surface remarks about 'caste acceptance' are taken as truisms leading to sweeping conclusions about the 'acceptability' of cross-region brides. ${ }^{120}$

${ }^{116}$ Interview: Hindu Bride BH $n$ 1 7, Rohtak District, Haryana, 11 October 2011.

${ }^{117}$ Interview: Hindu cross-region bride $\mathrm{BH} n_{53}$, Rohtak District, Haryana, 23 September 2014 .

${ }^{118}$ Chandra T. Mohanty, Feminism Without Borders: Decolonizing Theory, Practising Solidarity, Durham: Duke University Press, 2003, p. 21.

${ }^{119}$ Kaur, 'Marriage and Migration', p. 78.

${ }^{120}$ Chaudhry and Mohan, 'Of Marriage and Migration'; Mishra, 'Sex Ratios'. 


\section{The inter-generational burden of caste prejudice}

Some scholars assert that children of cross-region unions are accepted unequivocally within the caste brotherhood and are not treated differently in matrimony. ${ }^{121}$ For instance, Mishra relies on a very small sample of seven cross-region brides to conclude that all such children face no caste-based discrimination. ${ }^{122}$ Ironically, she critiques reservations about caste acceptance of these children voiced by other scholars ${ }^{123}$ by stating that it is 'misleading to generalise ... on the basis of a few brides'. ${ }^{124}$

However, my extensive research belies such assimilationist contentions and proves that caste stigmatization continues intergenerationally, with children of these unions categorized into a lower social category than, and perceived as 'inferior' to, those of local women. Caste elders are quick to point out that 'A, B and C grade categories exist everywhere. Similarly, grading or hierarchies cannot be eliminated societally for people. You've to accept that. It will be applicable for children of such inter-region inter-caste marriages. ${ }^{125}$ Despite the prevalence of local patriarchal norms by which a child's caste is defined by the father's, the children of cross-region unions are often labelled 'diluted' Jats.

This pernicious belief raises concerns about such children's ability, in adulthood, to enter into matrimony locally within caste endogamous groups. Jat villagers assert that '(n)obody will want to marry them. Our community will then ask the question: "Whose children are these? Where's the mother from? What caste is she?""126 Apprehensions are voiced more sharply for male offspring as local families also fear that their daughters will bear 'the stigma of a low caste mother-in-law and their children too will have to bear the ignominy of having low caste blood in them'. ${ }^{127}$ The solution offered by locals is that 'their children

${ }^{121}$ Chaudhry and Mohan, 'Of Marriage and Migration'; Kaur, 'Marriage and Migration Citizenship'; Mishra, 'Sex Ratios'.

${ }_{122}$ Mishra, 'Sex Ratios'.

${ }^{123}$ Chowdhry, Political Economy of Production and Reproduction; Reena Kukreja and Paritosh Kumar, Tied in a Knot. Cross-region Marriages in Haryana and Rajasthan: Implications for Gender Rights and Gender Relations, New Delhi: Tamarind Tree Films, 2013 .

${ }^{124}$ Mishra, 'Sex Ratios', p. 75.

${ }^{125}$ Interview: Meher Singh Dahiya, Secretary, Dahiya Khap, Sisana, Sonepat District, Haryana, 24July 2014.

${ }^{126}$ Focus group: Jat men FGJM $n$ 1, Rohtak District, Haryana, 13 October 2011.

${ }^{127}$ Focus group: Jat women FGJW $n$ 1, Rohtak District, Haryana, 8 October 2011. 
will also have to be married just the way their fathers were forced to. They'll have to arrange matches from outside. They won't get married within the community. ${ }^{, 28}$ To resolve the marriage conundrum of caste-ambiguous offspring, one caste council has proposed a strategy used historically to resolve similar crises.

Each village has $5^{\mathrm{O}-100}$ families in inter-state marriage-both inter-caste and inter-region. Eventually, there will be $5^{\circ}$ odd such families living in one village and 100 in another. They would constitute a new group within Dahiya Khap and undertake marriage relations between themselves. ${ }^{129}$

Families in cross-union marriages with young children acknowledge this harsh reality. One husband said: 'It is not just one family getting a bride from outside. In this village and other neighbouring ones, there are forty or fifty who have done the same. We will marry within that group if we cannot get a match from our caste group. ${ }^{\text {'130 }}$

My findings about inter-caste children are supported by other scholars. Sonali Mukherjee's study in another district of Haryana mentions that such offspring are referred to as 'people of low social esteem'. ${ }^{131}$ Leela Dube, a respected Indian sociologist, in her work on inter-caste marriages among the Rajputs in North India with low but 'clean' caste women, that is, women from caste groups not engaged in ritually polluting activities, also noted that their children, despite being called Rajputs, were given a lower Rajput status than that of their fathers. ${ }^{132}$ Prem Chowdhry, in her study of Haryanvi society, hypothesized that caste-ambiguous children would most likely encounter hurdles in obtaining marriage proposals. ${ }^{133}$

The contentious nature of 'assimilation' and 'integration' of brides within the kin network is further evident from the experience of some families unable to obtain local brides for brothers of men with crossregion wives $(\mathrm{n}=7)$. The stigma of a low-caste woman in the household deters local families from negotiating matrimony with such families. In a majority of cases, they have had to bring in another cross-region bride.

${ }^{128}$ Focus group: Jat men FGJM $n$ 1, Rohtak District, Haryana, 13 October 2011.

${ }^{129}$ Interview: Dahiya Khap Panchayat, Sonepat District, Haryana, 21 July 2012.

${ }^{130}$ Interview: Hindu husband $\mathrm{HH} n 6$, Rohtak District, Haryana, 9 October 2011.

${ }^{131}$ Sonali Mukherjee, 'Skewed Sex Ratio and Migrant Brides in Haryana: Reflections from the Field', Social Change, Vol. 43, No. 1, 2013, pp. 43, 37-52.

${ }^{132}$ Leela Dube, 'Caste and Women', Caste: Its Twentieth Century Avatar, M.N. Srinivas (ed.), Delhi: Penguin, 1996, pp. 19, 1-27.

${ }^{133}$ Prem Chowdhry, Contentious Marriages, Eloping Couples: Gender, Caste, and Patriarchy in Northern India, Delhi: Oxford University Press, 2007, p. 300. 
Recently, the Satrol Khap, ${ }^{134}$ one of the Jat caste councils (Khap Panchayat) in Haryana, passed a resolution to allow inter-caste marriages to take place locally in light of Haryana's skewed sex ratio. ${ }^{135}$ The resolution has been welcomed by many as a historic step towards dismantling caste hierarchies enforced through marriage norms. However, the resolution has been opposed by one of its own Tapas ${ }^{136}$ which staged a walkout during the declaration on grounds that it wasn't consensual. ${ }^{137}$ Time-based research needs to be undertaken to ascertain how established hierarchies of caste will respond-due to the relatively new nature of such marriages, the number of children is still small and many are not yet of marriageable age. For the moment, families bravely assert that, 'if we are unable to find brides for our sons here, then we will fetch brides from elsewhere, just like we did ${ }^{138}$ and in the process, recreate the cycle of victimization and stigmatization for their wives and children.

\section{Resistance strategies of cross-region brides}

Dalit cross-region brides, having historically internalized subservient behaviour vis-à-vis the upper castes to avoid punishment for deviating from caste-sanctioned behaviour, end up reproducing it within their new homes. This 'submissive' stance ranges from acquiescing to cooking separately to not attending family or kin celebrations or ceremonies. Though these acts can be interpreted as docile forms of self-policing, these should not detract from agency displayed by the brides by which they adopt a 'culture of subversion' and practise

${ }^{134}$ Satrol Khap comprises 42 villages in the Narnaund region of Hisar District in Haryana. It is an 'all-caste' council, unlike other Khaps that are Got-specific.

${ }^{135}$ Manveer Saini, 'Haryana's Biggest Khap Panchayat Scripts HistoryAllows Inter-caste Marriages', The Times of India, 21 April 2014: http://timesofindia.indiatimes.com/india/Haryanas-biggest-khap-panchayat-scriptshistory-allows-inter-caste-marriages/articleshow/34016585.cms, [accessed 16 July 2017 ].

${ }^{136}$ 'Tapa' is a unit of Khap Panchayat that comprises a specific number of villages. Several Tapas come together to constitute one Khap. In the case of Satrol Khap, Petwar Tapa controls a cluster of 12 villages in Hisar District of Haryana.

${ }^{137}$ Interview: Phool Kumar Petwar, Chief, Petwar Tapa, Satrol Khap Panchayat, Narnaund, Hisar District, Haryana, 22 July 2014; Sukhbir Siwach, 'Haryana Khap Unit Opposes Change in Marriage Norms', The Times of India, 23 April 2014: http://timesofindia.indiatimes.com/india/Haryana-khap-unit-opposes-change-inmarriage-norms/articleshow/34088789.cms, [accessed 16 July 2017].

${ }^{138}$ Interview: Hindu bride BH $n_{1}$ 8, Rohtak District, Haryana, 11 October 2011. 
'concealed forms of rebelling'. ${ }^{139}$ Very much like local brides, they try to get back at their tormentors through ordinary acts of rebellion such as non-compliance, non-comprehension of orders or delaying tactics to strike advantageous 'patriarchal bargains' with other family members.

The internalization of hegemonic patriarchal values about marriage and of the social shame associated with 'deserted' women makes flight the last and the least preferred option for Dalit cross-region brides. Many confide that 'the head of our natal family will hang in shame if we go back with a failed marriage. What will people say: that you married your daughter so far away and yet it couldn't work. We will be dependent on the bheekh (alms) of our brother and his wife. ${ }^{140}$ Their financial precariousness due to lack of ownership of assets such as land makes it harder for them to conceptualize returning home and becoming dependent on the largesse of their brothers or other male members of the family for their survival.

Despite this, some women do opt to end their marriages by running away. My research in two natal regions involved interviews with two such Dalit women. Interestingly, their elder sisters had arranged their marriages with men in their conjugal family or in the village. In both cases, the sisters had also assisted them in making their escape. The sisters' help is an important detail as it reveals the difficulty for travelnaïve village women, who must use multiple modes of transport, with travel time ranging from two to four days, to negotiate their way right across the country. Both women, one in West Bengal and the other in Odisha, currently reside with their brothers and work as casual agricultural wage labourers: 'I have to work to earn my living. If I work, only then do I get to eat. Who will feed me just like that? ${ }^{141}$ It is hard to arrive at conclusions based on such a small sample. More longitudinal research has to be undertaken to ascertain the post-return socio-economic conditions of such women.

Brides try persuading their husbands to set up separate households as that would allow them, to some extent, to get away from intimate acts of caste prejudice and continual demands on their labour. They succeed in cases where their husbands are more sensitive to their wives predicament, have a modicum of economic independence, have already received their share of the paternal land, or are totally dependent on the wives due to old age or infirmity. A Dalit bride now living in

\footnotetext{
${ }^{139}$ Mohanty, Feminism Without Borders, p. 164.

${ }^{140}$ Interview: Hindu bride $\mathrm{BH} n 64$, Rohtak District, Haryana, 25 September 2014.

${ }^{141}$ Interview: Hindu bride $\mathrm{BH} n 44$, Balasore District, Odisha, 28 November 2011.
} 
her independent household commenting on caste-ist barbs made by female neighbours, stated: 'They call me Churhi or Chamaran. I retort back: "Big deal. Now that I rule this house, I will instead be called the 'Queen' of my husband's heart!"'142 Similarly, other brides recall responding to being called 'neech jaat' (low caste). They accuse the conjugal families of holding duplicitous attitudes towards caste. They state: 'At the time of our marriage, where did your concerns about marrying into the same caste vanish (shaadi karte samay jaat kahan gayee thi)? All you wanted was a wife'; 143 'Why did you go to Bangal (West Bengal) for a bride? Our families did not send an invitation to you (nyota na bheja tha) to come there and marry us. You came begging for a wife to our village'; ${ }^{144}$ and 'At that time, you were pleading with my father to agree to the alliance. You knew we were low caste.' 145

Such overt subjectivity of cross-region brides, though welcome, is rare as these challenges often result in retaliatory action by family members who use violence to intimidate them or publicly ridicule them in the community. Villagers often told me that some brides were 'characterless' or 'did not behave according to societal norms' (uska chal chalan theek nahin). ${ }^{146}$

Consequently, brides often resort to random and subtle forms of resistance that are 'not organized, formal, or necessarily public' of normality ${ }^{147}$ to avoid such disciplining mechanisms. These are best understood through James Scott's concept of the 'infrapolitics'148 of 'everyday acts of resistances' ${ }^{149}$ that 'stop short of outright defiance,

${ }^{142}$ Interview: Hindu bride BH $n 64$, Rohtak District, Haryana, 25 September 2014.

${ }^{143}$ Interview: Hindu Bride BHn62, Rohtak District, Haryana, 25 September 2014.

${ }^{144}$ Interview: Hindu Bride $\mathrm{BH} n$ 10, Rohtak District, Haryana, 9 October 2011.

${ }^{145}$ Interview: Hindu bride BH $n 67$, Rohtak District, Haryana, 25 September 2014.

${ }^{146}$ Interviews: Conjugal region Village man VMC $n 8$, Mewat District, Haryana, 29 August 2014; Conjugal region Village man VMCn2, Rohtak District, Haryana, 8 October 2011.

${ }^{147}$ Anna Johansson and Stellan Vintagen, 'Dimensions of Everyday Resistance', Critical Sociology, Vol. 42, No. 3, 2016, pp. 421, 417-435.

${ }^{148}$ According to James Scott, the 'infrapolitics' of 'everyday acts of resistances' comprise a range of activities such as 'footdragging, dissimulation, false-compliance, pilfering, feigned ignorance, slander, arson, sabotage, and so forth': see J. Scott, Weapons of the Weak: Everyday Forms of Peasant Resistance, New Haven: Yale University Press, 1985 , p. 29.

${ }^{149}$ James C. Scott, Domination and the Arts of Resistance: Hidden Transcripts, New Haven: Yale University Press, 1990. 
and are more ordinary, indirect strategies of opposition, that often exist under the radar of the dominant group.. 150

Female family relatives of the brides' husbands and local women belonging to the same caste group as conjugal families constitute one big group against whom the brides' 'everyday acts of resistance' are undertaken. The brides' 'infrapolitics' ranges from foot dragging over household chores in a joint family establishment, taking longer than usual to complete jobs assigned to them, feigning non-comprehension of requests, spending more time fussing over their children, or pretending to fall sick. The cross-region brides are quick to state that such 'hidden transcripts' ${ }^{151}$ of everyday resistance, if caught, invite immediate reprisal in the form of verbal and physical abuse from either the mother-in-law or the husband. To elaborate, a bride from Maharashtra who was constantly abused, both verbally and physically, by her husband and her in-laws, told me that she chose to feign sleep or tiredness and would lie in bed for large parts of the day. Her rationale? 'If they abuse me all the time, why should I work for them? I will not get up and do chores for them.' ${ }^{, 152}$

The irony of their resistance, either against female family members or village women, lies in the fact that both categories of women, as either subordinate or dominant, constitute members of a larger subordinate group of 'women' within the hegemonic patriarchal ideology. This underscores the need to recognize the fluid and contextspecific nature of power hierarchies. For example, their jethanis ${ }^{153}$ might chafe against patriarchal controls and restraints, yet they impose similar constraints on all incoming brides. However, according to caste ideology, an alliance is created between dominant and subordinate groups belonging to a particular caste group, either between men and women or between various ranks of women within it.

${ }^{150}$ Maria Kastrinou-Theodoropoulou, 'Editorial Note: Political Anthropology and the Fabrics of Resistance', Durham Anthropology Journal, Vol. 16, No. 2, 2009, pp. 3, $3-7 \dot{5}$

${ }^{1}$ James Scott, in his work on Malay plantation workers, put forward the concept of hidden transcripts in shaping everyday resistance strategies of subordinate groups. It refers to the resistance and rebellion undertaken by the subordinate groups, beyond the observation or knowledge of dominant elites, against them. For more, see Scott, Domination and the Arts of Resistance.

${ }^{152}$ Interview: Hindu bride BHn62, Rohtak District, Haryana, 25 September 2014.

153 'Jethani' is a husband's elder brother's wife. 
In instances where families have more than one cross-region bride $(n=23)$, either sisters or two cross-region brides brought in at different periods of time, the familial power dynamics are tilted in the brides' favour. They have more opportunities to manoeuvre advantageous patriarchal bargains and to register stronger protest against the caste discrimination within the family and in the community. Arranging marriages of women, either siblings or other women from natal kin or villages, with men in their conjugal families or communities is one strategy that the brides employ to push against the gradual shrinkage of private and public space available to them, carve out non-hostile spaces where they can interact without the overarching theme of caste-othering vitiating their personal interactions, and enact 'hidden transcripts' of resistance.

Another resistance strategy involves the brides deliberately and voluntarily choosing to shun the company of female relatives or local women by opting for the isolation of their rooms and consequently denying their 'tormentors' the opportunity to assert caste supremacy over them. One bride explained: 'I do not speak to any village women. They just make fun of me. So what is the point of talking to them? It's better that I stay indoors and not interact with them. ${ }^{154}$ If there are more brides from the same region, they choose to spend time with one another, thus forming a tightly knit, exclusive group. Other brides opt to undermine unequal relations of power by 'regulating' their behaviour to thwart opportunities for village or kin women to insult them. For instance, instead of going with others to collect firewood, fodder or water, they opt to do it separately or at different periods of the day, as described by a bride: 'The village water tap is a distance from here. I go there only after all others have filled water and when no one is there. I don't speak to anyone. ${ }^{155}$ In all these narratives of 'everyday acts of resistance', what must not be ignored is that these women are still victims of caste prejudice. The brides also performed resistance by agreeing to participate in this research, to share their deeply personal narratives in one-on-one interviews and focus groups, and to challenge dominant perceptions about their assimilation. Their 'veiled discourse(s) of dignity and self-assertion within the public transcript', ${ }^{156}$ as counter-hegemonic strategies against caste discrimination and caste policing, also reinforce the suspect nature

\footnotetext{
${ }^{154}$ Interview: Bride BH $n$ 13, Rohtak District, Haryana, 11 October 2011.

${ }^{155}$ Interview: Bride $\mathrm{BH} n 1$ 7, Rohtak District, Haryana, 11 October 2011.

${ }^{156}$ Scott, Weapons of the Weak, p. 137.
} 
of their acceptance or assimilation as caste equals within conjugal families and communities in Haryana.

\section{Conclusion}

I have argued that to build a totalizing narrative about these brides, most of whom are Dalits, as 'integrated' or 'assimilated' or of such marriages as 'acceptable' or 'normal' is, at best, misleading. This edifice, I suggest, is weakened, by two fault lines: theoretical and empirical. The theoretical weakness within the existing literature lies in its tendency to homogenize all brides within an overarching category of Indian women while ignoring attributes like caste or ethnicity that distinctly shape the trajectory of their experiences, gender relations, and dynamics of power, an oversight that Dalit feminism has unmistakably exposed in mainstream Indian scholarly work. The associated empirical failure lies in the inability to deploy research methods that interrogate Dalit brides' position within the intersection of caste, class, and patriarchy or to use research tools that provide Dalit brides with a platform to share narratives of caste oppression.

These two failures 'result in political agendas and public policies that fail to be adequately responsive to the interests of women from ... marginalized groups'. ${ }^{157}$ Instead of dismantling and exposing the sham rhetoric of 'caste integration' or 'caste accommodations' made by dominant castes, who are the biggest perpetrators of local caste violence, such scholarly conclusions end up masking, legitimizing, and reinforcing the caste violence that the brides experience. Contentions such as that of Mishra that 'caste difference between the spouses is an important factor, not in terms of it being a ground for discrimination, but in terms of the adjustments that cross-region brides have to make to follow new caste practices after marriage ${ }^{158}$ become deeply suspect in the face of pervasive societal prejudice against Dalits. Are these Dalit brides taught to adopt discriminatory 'caste practices' of dominant castes towards local Dalits? Or do they have to 'adjust' to discriminatory practices as exhibited towards them? Answers to these questions have profound implications for shaping gender relations

${ }^{157}$ Uma Narayan, Dislocating Cultures: Identities, Traditions, and Third World Feminism, London: Routledge, 1997, p. 44.

${ }^{158}$ Mishra, 'Sex Ratios', p. 70. 
and gender dynamics inside and outside households. We are left with statements that these women do not face 'societal or familial violence'. ${ }^{159}$

These 'inter-caste' marriages, instead of promoting caste 'integration', heighten caste-based repression against these brides. Since such marriages can be interpreted as political acts that threaten to destabilize caste hierarchies and attendant privileges, caste violence constitutes a pedagogical tool to instruct Dalit women not to overstep caste boundaries. Local unequal hierarchies of power and caste relations are not changed as men from dominant caste groups in Haryana enter into cross-region 'inter-caste' marriages. The need to maintain a hegemonic hold over the resources and privileges attendant upon their upper caste status prevents these very men from marrying local Dalit women.

The uniqueness of caste violence lies in the fact that, unlike local Dalits who experience caste-based discrimination in the public arena, these brides experience exclusion and humiliation in both public and private spaces: from the local community and from the conjugal family members. Caste discrimination is also rendered invisible as the perpetrators share familial or kin bonds with these brides, thus making it well-nigh impossible to prove its occurrence or to seek intervention. Dalit status also alters the dynamics of gender relations within the household and community by creating new forms of gender subordination for the Dalit cross-region brides. Although their free labour is prized, they are also simultaneously subjugated through caste-discriminatory behaviours used by conjugal family members as strategic devices that minimize their ability to resist overwork or abuse, reduce their self-esteem through constant questioning of their identity, and isolate them socially by denying them entry into the community circle.

There is a great need to acknowledge 'differences' of caste, class, ethnicity, location, and even colour, within the constructed category of cross-region brides in significantly altering their status and reception in conjugal homes and communities. Given the increasing local Dalit assertion against dominant-peasant caste oppression, it is also worthwhile examining the local Dalit organizations' perspective on these Dalit cross-region brides. While this research did not uncover any evidence of Dalit alliance-building with the brides, it should not

${ }^{159}$ Ibid., p. 77 . 
be taken as proof that Dalit politics in Haryana ignores or overlooks it. Spatial segregation of castes in villages through caste-specific neighbourhoods as well as restrictions placed by conjugal families on the incoming brides' freedom of movement and association can be considered as some of the reasons that thwart solidarity linkages being forged between these two separate sets of Dalits. However, more detailed and longitudinal studies need to be undertaken to discover the trajectory of local Dalit politics vis-à-vis Dalit cross-region brides.

The failure to situate these marriages within the context of polarized caste relations, caste contestations, and caste violence against local Dalits in Haryana creates a flawed understanding of motives for such alliances and treatment of brides. The denial of caste as an analytical category reaffirms the Dalit feminist contention that mainstream Indian feminists commit epistemic violence on Dalit women by homogenizing all women's experiences and by ignoring interconnections between caste, patriarchy, and gender. ${ }^{160}$ Feminists everywhere can acquire greater understanding of the impact of intersecting oppressions of patriarchy and caste on all cross-region brides, including Dalit ones, if 'reductive assumptions' about their assimilation or integration are avoided. Though the oversight of scholars might perhaps not be intentional, the consequences for Dalit brides are devastating. The current distorted knowledge production and its circulation have implications on how activists, women's organizations, government agencies, and policy planners understand and address the concerns of cross-region brides.

${ }^{160}$ Rege, Writing Caste/Writing Gender. 